\title{
PERBANDINGAN METODE PENYELESAIAN PERMASALAHAN OPTIMASI LINTAS DOMAIN DENGAN PENDEKATAN HYPER-HEURISTIC MENGGUNAKAN ALGORITMA REINFORCEMENT LEARNING-LATE ACCEPTANCE
}

\author{
Anang Firdaus ${ }^{1}$, Ahmad Muklason*2, Vicha Azthanty Supoyo ${ }^{3}$ \\ $\mathbf{1 , 2 , 3}$ Institut Teknologi Sepuluh Nopember Surabaya \\ Email: 1anangfirdaus05@gmail.com, ${ }^{2}$ mukhlason@is.its.ac.id, ${ }^{3}$ vichasupoyo@gmail.com \\ *Penulis Korespondensi
}

(Naskah masuk: 14 Februari 2020, diterima untuk diterbitkan: 15 Oktober 2021)

\begin{abstract}
Abstrak
Sebuah organisasi terkadang membutuhkan solusi untuk permasalahan optimasi lintas domain. Permasalahan optimasi lintas domain merupakan permasalahan yang memiliki karakteristik berbeda, misalnya antar domain optimasi penjadwalan, rute kendaraan, bin packing, dan SAT. Optimasi tersebut digunakan untuk mendukung pengambilan keputusan sebuah organisasi. Dalam menyelesaikan permasalahan optimasi tersebut, dibutuhkan metode pencarian komputasi. Di literatur, hampir semua permasalahan optimasi dalam kelas NP-hard diselesaikan dengan pendekatan meta-heuristics. Akan tetapi meta-heuristic ini memiliki kekurangan, yaitu diperlukan parameter tunning untuk setiap problem domain yang berbeda. Sehingga pendekatan ini dirasa kurang efektif. Oleh karena itu diperlukan pendekatan baru, yaitu pendekatan hyper-heuristics. Metode hyperheuristic merupakan metode pencarian komputasi approximate yang dapat menyelesaikan permasalahan optimasi lintas domain dengan waktu lebih cepat. Lintas domain permasalahan yang akan diselesaikan ada enam, yaitu satisfiability (SAT), one dimensional bin packing, permutation flow shop, personnel scheduling, travelling salesman problem (TSP), dan vehicle routing problem (VRP). Dalam meningkatkan kinerja, penelitian ini menguji pengaruh dari adaptasi algoritma Reinforcement Learning (RL) sebagai strategi seleksi LLH dikombinasikan dengan algoritma Late Acceptance sebagai move acceptance, selanjutnya disebut algoritma Reinforcement Learning-Late acceptance (RL-LA). Untuk mengetahui efektivitas performa dari algoritma RLLA, performa algoritma RL-LA yang diusulkan dibandingkan dengan algoritma Simple Random-Late Acceptance (SR-LA). Hasil dari penelitian ini menunjukan bahwa algoritma yang diusulkan, i.e. RL-LA lebih unggul dari SR-LA pada 4 dari 6 domain permasalahan uji coba, yaitu SAT, personnel scheduling, TSP, dan VRP, sedangkan pada domain lainnya seperti bin packing dan flow shop mengalami penurunan. Secara lebih spesifik, RL-LA dapat meningkatkan peforma pencarian dalam menemukan solusi optimal pada 18 instance dari 30 instance atau sebesar 64\%, dan jika dilihat dari nilai median dan minimum metode RL-LA lebih unggul $28 \%$ dari metode SR-LA. Kontribusi utama dari penelitian ini adalah studi performa algoritma hibrida reinforcement learning dan late acceptance dalam kerangka kerja hyper-heuristics untuk menyelesiakan permasalahan optimasi lintas domain.
\end{abstract}

Kata kunci: Optimasi Lintas Domain, Hyper-heuristic, High level heuristic, Reinforcement Learning, Late Acceptance

\section{COMPARISON OF CROSS DOMAIN OPTIMIZATION COMPLETION METHOD FOR HYPER-HEURISTIC APPROACH USING REINFORCEMENT LEARNING-LATE ACCEPTANCE ALGORITHM}

\begin{abstract}
An organization sometimes needs solutions to cross domain optimization problems. The problem of cross domain optimization is a problem that has different characteristics, for example between domain optimization scheduling, vehicle routes, bin packing, and SAT. This optimization is used to support an organization's decision making. In solving these optimization problems, a computational search method is needed. In the literature, almost all optimization problems in NP-hard class are solved by meta-heuristics approach. However, this metaheuristic has drawbacks, namely tuning parameters are needed for each different problem domain. So this approach is considered less effective. Therefore a new approach is needed, namely the hyper-heuristics approach. Hyper-heuristic method is an approximate computational search method that can solve cross domain optimization problems faster. In this final project there are six cross domain problems to be solved, namely
\end{abstract}


satisfaction (SAT), one dimensional bin packing, permutation flow shop, personnel scheduling, traveling salesman problem (TSP), and vehicle routing problem (VRP). In improving performance, this study examines the effect of the adaptation of the Reinforcement Learning (RL) algorithm as LLH selection combined with the Late Acceptance algorithm as a move acceptance. The results of this study indicate that there are 4 out of six problem domains that have improved performance, namely the SAT, personnel scheduling, TSP, and VRP, while in other domains such as bin packing and flow shop has decreased.

Keywords: Cross Domain Optimization, Hyper-heuristic, High level heuristic, Reinforcement Learning, Late Acceptance

\section{PENDAHULUAN}

Permasalahan optimasi saat ini berkembang menjadi masalah yang kompleks karena besarnya jumlah input dataset dan batasan-batasan yang harus terpenuhi dalam menentukan optimalitas (Rego, C., Gamboa, D., Glover, F. \& Osterman, C., 2011). Saat ini terdapat berbagai macam domain permasalahan optimasi kombinatorial, seperti permasalahan optimasi vehicle routing problem (VRP), flow shop, bin packing, dan penjadwalan. Sebuah organisasi terkadang juga membutuhkan banyak optimasi untuk mendukung bisnisnya. Sebagai contoh perusahaan yang bergerak dalam bidang logistik tidak hanya membutuhkan optimasi untuk satu domain, tetapi membutuhkan optimasi untuk banyak domain, yaitu optimasi penjadwalan sopir, rute kendaraan, dan pengemasan barang (bin packing) sehingga permasalahan ini dapat disebut dengan permasalahan lintas domain.

Dalam menyelesaikan banyak domain permasalahan optimasi dibutuhkan berbagai jenis metode atau algoritma pencarian komputasi. Metode atau algoritma pencarian dalam menyelesaikan masalah optimasi dikelompokkan menjadi dua kelompok, yaitu algoritma exact dan algoritma approximate (Ochoa, G., 2014). Algoritma exact digunakan dalam menyelesaikan permasalahan optimasi sederhana. Dalam menyelesaikan masalah sederhana, algoritma exact dapat menemukan solusi yang paling optimal dalam waktu singkat. Namun, pada permasalahan optimasi yang kompleks seperti TSP, rute kendaraan, dan penjadwalan dengan input dataset yang besar, algoritma exact belum mampu mencari solusi yang paling optimal dalam waktu singkat. Oleh karena itu, algoritma approximate seperti heuristik, meta-heuristic, dan hyper-heuristic digunakan sebagai pilihan dalam menyelesaikan permasalahan optimasi yang kompleks.

Algoritma approximate lebih mengutamakan pencarian yang cepat sehingga efisien daripada pencarian yang lengkap (linear). Hal tersebut menyebabkan hasil solusi yang ditemukan dengan metode ini bukanlah hasil yang paling optimal, tetapi cukup baik dan dapat diselesaikan dalam waktu singkat (polynomial).

Pengembangan metode heuristik adalah metaheuristic yang menyelesaikan permasalahan optimasi secara spesifik berdasarkan karakteristik satu permasalahan tertentu (Burke, E.K., Hyde, M.,
Kendall, G., Ochoa, G., Ozcan, E., \& Woodward, J. R., 2006). Dalam menyelesaikan banyak permasalahan optimasi, meta-heuristic harus mendeskripsikan dan memodelkan setiap domain permasalahan, serta menemukan metode pencarian yang tepat dalam menyelesaikan permasalahan setiap domain secara spesifik. Penyelesaian permasalahan optimasi secara spesifik membutuhkan biaya yang mahal dan waktu yang lama karena jika ada domain permasalahan baru, metode tersebut harus memodelkan masalah dan memodifikasi metode pencarian dari awal. Penerapan metode metode tersebut dapat memperlambat proses pengambilan keputusan untuk dalam menemukan solusi optimal untuk banyak permasalahan optimasi yang berbeda (lintas domain). Oleh karena itu, perlu suatu metode yang dapat menyelesaikan berbagai permasalahan optimasi secara general sehingga dapat mempercepat penyelesaian masalah dalam mencari solusi (Burke, E.K. \& Kendall, G., 2013).

Hyper-heuristic adalah metodologi otomatis untuk mencari atau membuat heuristik dalam meningkatkan generalitas domain permasalahan dan instance berbagai domain permasalahan optimasi yang kompleks (Burke, E. K. , Hyde, M. , Kendall, G., Ochoa, G., Ozcan, E. \& Woodward, J.R., 2006). Walaupun hyper-heuristic dapat meningkatkan generalitas pencarian komputasi pada banyak domain permasalahan optimasi, tetapi hasil pencarian hyper-heuristic tidak selalu optimal untuk semua domain permasalahan (Burke, E. K. \& Kendall, G., 2013). Hal tersebut disebabkan oleh perbedaan karakteristik setiap domain permasalahan.

Strategi high level heuristic yang diusulkan, diuji coba pada kerangka kerja Hyper-heuristics Flexible (HyFlex). Terdapat enam domain permasalahan kombinatorial pada framework HyFlex, yaitu travelling salesman problem (TSP), vehicle routing problem (VRP) satisfiability (SAT), one dimensional bin packing $(B P)$, permutation flow shop $(F S)$ dan personel scheduling (PS), (Ochoa, G., 2012).

Meta-heuristic merupakan algoritma yang dapat menyelesaikan masalah optimasi kompleks jika diselesaikan dengan algoritma eksak. Metode heuristik adalah metode yang digunakan untuk mencari solusi suatu masalah dimana solusi yang ditemukan merupakan feasible solution yang terbaik 
(Hillier, F. and Lieberman, G., 2010). Dalam pencarian solusi yang efisien dan komprehensif, metode meta-heuristic menggunakan mekanisme yang meniru perilaku sosial ataupun strategi yang ada di alam.

Algoritma meta-heuristic memiliki kecepatan pencarian solusi optimal yang lebih baik daripada metode tradisional (Madi, M., Markovi, D. \& Radovanovi, M., 2013). Metode ini juga memberikan hasil yang lebih baik dibanding metode heuristik karena metode ini akan selalu berusaha untuk keluar dari solusi local optima. Meskipun tidak ada jaminan bahwa solusi yang ditemukan merupakan solusi yang optimal, metode metaheuristic yang dibangun dengan baik dapat memberikan solusi yang mendekati solusi optimal (Szepesvári, C., 2010).

Reinforcement Learning (RL) merupakan sub area machine learning yang menitikberatkan pada bagaimana sebuah agent melakukan tindakan di lingkungannya. Dalam hal ini, agent berusaha untuk mengumpulkan reward sebanyak mungkin dalam waktu jangka panjang (Szepesvári, 2010). Dalam setiap iterasi langkah yang diambil, RL akan menentukan salah satu aksi dari banyak aksi yang mungkin dilakukan. Berikutnya, agent akan menerima reward atau punishment dari lingkungan atas aksi spesifik yang dilakukannya. Dalam hal ini, agent tidak mengetahu mana aksi terbaik yang harus dilakukan di beberapa state. Dengan demikian agent harus melakukan trial and error dengan melakukan beberapa aksi yang berbeda termasuk dengan urutan yang berbeda serta belajar dari pengalamannnya (Sutton and Barto, 2018)

Berbeda dengan tipe pembelajaran lainnya, RL lebih berfokus kepada goal-directed learning dan interaksi yang dilakukan dengan lingkungan. Feedback yang diberikan kepada agent bersifat evaluatif, sedangkan pada tipe pembelajaran lain, misalnya pada supervised learning feedback yang diberikan bersifat instruksional. Agent RL tidak diberitahu aksi mana yang benar maupun salah melainkan diberikan reward signal sesuai dengan aksi yang dilakukan, yang menandakan seberapa baik aksi yang telah diambil tersebut. Karenanya dibutuhkan eksplorasi dan pembelajaran yang bersifat trial-and-error agar Agent dapat bertindak sesuai dengan yang seharusnya.

Late Acceptance Strategy (LAS) adalah metode baru dalam metaheuristic yang memiliki strategi membandingkan antara kandidat solusi dengan salah satu solusi yang telah muncul pada beberapa iterasi sebelumnya (Özcan, 2009). Gambar 1 mengilustrasikan cara kerja algoritma LAS.

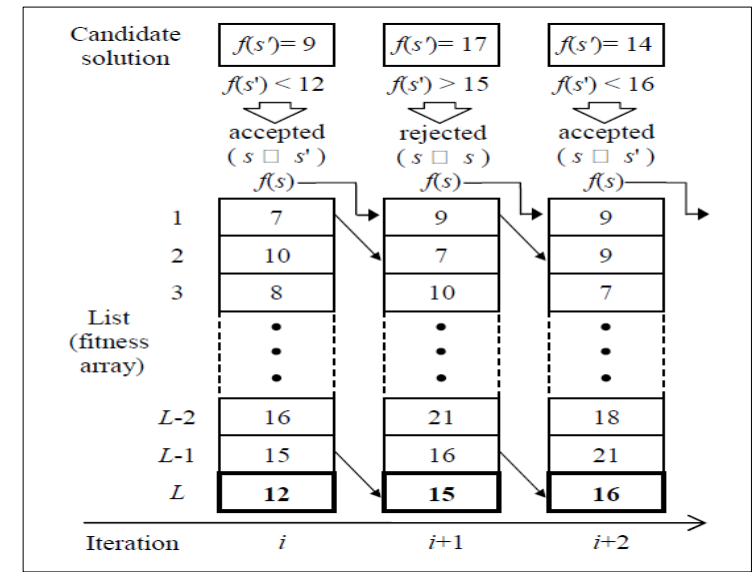

Gambar 1 Ilustrasi Iterasi Pada Eksekusi LAS

Hal tersebut menjadi pembeda antara LAS dengan metode pencarian metaheuristic lainnya seperti Simulated Annealing ataupun Hill Climbing yang memiliki strategi untuk membandingkan kandidat solusi dengan solusi terakhir secara langsung. Namun LAS termasuk dalam kelompok teknik pencarian perulangan meskipun memiliki tingkat mekanisme penerimaan yang lebih tinggi.

Dapat dilihat pada Gambar 1 bahwa kandidat solusi pada iterasi ke-i dan ke-(i+2) dapat diterima karena memiliki nilai yang lebih kecil dibandingkan dengan solusi pada urutan ke-L, sehingga kandidat solusi tersebut ditambahkan ke dalam daftar. Sedangkan untuk iterasi ke-(i+1), kandidat solusinya ditolak karena memiliki nilai yang lebih tinggi dibandingkan dengan solusi pada urutan ke-L, yang menyebabkan nilai solusi terakhir bernilai sama dengan nilai solusi sebelumnya.

Hyper-heuristic adalah sebuah metode yang penerapan pencariannya dilakukan pada level heuristik, yaitu dengan melakukan pemilihan dan menggunakan heuristik secara optimal agar dapat memecahkan suatu permasalahan (Burke, 2013). Pendekatan ini berbeda dengan pendekatan metaheuristic biasa dimana ruang-pencariannya (searchspace) berupa seluruh kemungkinan solusi, ruang pencarian hyperheuristic adalah semua kemungkinan low-level heuristic atau low-level heuristic search space yang dapat digunakan untuk memecahkan solusi (Harman, 2015). Hyper-heuristic melakukan proses pencarian pada domain permasalahan yang berbeda secara otomatis. Ide untuk mengotomatiskan desain heuristik telah ada pada tahun 1960, tetapi istilah hyper-heuristic baru diperkenalkan pada tahun 2000. Hyper-heuristic menggambarkan "heuristik untuk memilih heuristik" atau "heuristik untuk menghasilkan heuristik" (Burke \& Kendall, 2013).

Hyper-heuristic memberikan pendekatan yang memiliki tujuan untuk melakukan desain metode heuristik untuk menyelesaikan permasalahan komputasional yang rumit. Hyper-heuristic mendeskripsikan penggunaan heuristik untuk memilih heuristik lainnya pada kasus optimasi 
kombinatorial. Jadi, tujuan utama dari hyperheuristic adalah untuk membuat desain metode umum, yang dapat memberikan solusi yang layak berdasarkan penggunaan dari LLH (Low-Level Heuristic).

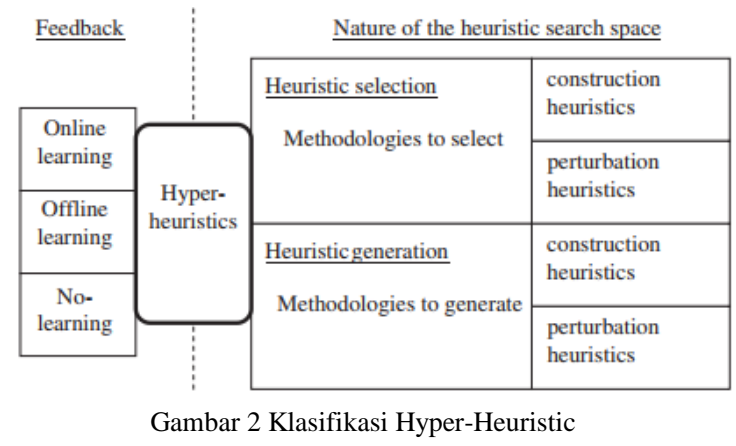

Sebagaimana diilustrasikan oleh Gambar 2, Hyper-heuristic terbagi menjadi dua dimensi klasifikasi, yaitu sifat ruang pencarian hyperheuristic dan perbedaan feedback dari implementasi low-level heuristics. Berdasarkan dimensi sifat ruang pencarian, hyper-heuristic terbagi lagi menjadi dua, yaitu seleksi dan generasi hyper-heuristic.

Masing-masing seleksi dan generasi hyperheuristic dibagi lagi berdasarkan sifat LLH sesuai dengan perbedaan antara paradigma pencarian konstruktif dan perturbatif. Konstruktif bekerja dengan mempertimbangkan solusi kandidat parsial (satu atau lebih komponen solusi hilang) dan secara iteratif membangun inisiasi solusi yang baru. Sementara itu, perturbatif mempertimbangkan inisiasi solusi lengkap dan sudah ada dan mengubahnya dengan memodifikasi satu komponen solusi atau lebih.

Hyper-heuristic terbagi menjadi 3 berdasarkan dimensi feedback sumber informasi pembelajaran, yaitu online, offline, dan no-learning. Dalam pembelajaran hyper-heuristic online, pembelajaran berlangsung ketika algoritma sedang menyelesaikan sebuah instance dari sebuah permasalahan, contohnya penerapan reinforcement learning pada seleksi heuristik, sedangkan dalam pembelajaran hyper-heuristic offline, mengumpulkan pengetahuan dalam bentuk peraturan atau program dari kumpulan instance pelatihan yang diharapkan akan menggeneralisasi untuk menyelesaikan kejadian yang tidak terlihat, contohnya penerapan learning classifier system dan genetic programming (Burke, 2006). Sedangkan no-learning tidak menggunakan pembelajaran apapun.

Hyper-heuristics flexible framework (HyFlex) adalah software kerangka kerja yang dirancang untuk memungkinkan pengembangan, pengujian, dan perbandingan algoritma pencarian heuristik tujuan umum iteratif seperti hyper-heuristics. Kerangka kerja ini dibangun dengan menggunakan bahasa Java dan biasa digunakan oleh banyak peneliti (Ochoa, 2012).
HyFlex pertama kali digunakan untuk mendukung kompetisi penelitian internasional pada tahun 2011 dan dikenal sebagai CheSC (CrossDomain Heuristic Search Challenge) 2011 (Ochoa, 2011). Di dalam Hyflex saat ini terdapat enam modul domain permasalahan yang diimplementasikan, yaitu one dimensional bin packing, vehicle routing problem, permutation flow shop, personnel scheduling, traveling salesman problem, dan satisfiability.

HyFlex telah ada pada Agustus 2010 saat peluncuran CheSC pada International Conference on Practice and Theory of Automated Timetabling (PATAT 2010). Saat ini telah banyak artikel implementasi hyper-heuristic yang dipublikasikan dengan HyFlex. Cross-Domain Heuristic Search Challenge bertujuan untuk melakukan pencarian dan pengoptimalan pada beberapa domain permasalahan (McCollum, 2011). State-of-the-art dari algoritma hyper-heuristics dapat dilihat di (Drake, 2020).

Penelitian sejenis sebelumnya dapat dilihat pada (Kumari, A.C. and Srinivas, K., 2016) yang menggunakan hyper-heuristics untuk menyelesaikan permasalahan klasterisasi modul software banyak tujuan dan (Hidayatul, 2019) untuk menyelesaikan permasalahan vehicle routing problem (VRP) banyak tujuan. Sedangkan penggunaan hyperheuristics untuk menyelesaikan permasalahan penjadwalan dapat dilihat di (KUSUMAWARDANI, 2019), (MUKLASON, 2019a), dan (MUKLASON, 2019b). Untuk studi hyper-heuristik dalam menyelesaikan permasalahan optimasi lintas domain juga dapat dilihat di (DJUNAIDY, 2019) dimana dalam studi ini algoritma yang digunakan adalah Variable Neighbourhood Search (VNS).

\section{METODE PENELITIAN}

Metodologi dari penelitian ini dapat dijelaskan sebagai berikut:

\subsection{Desain Algoritma}

Tahap ini merupakan penggabungan antara algoritma Reinforcement Learning untuk melakukan seleksi LLH dan Late Acceptence (LA) sebagai penerima solusi yang terbaik sesuai dengan permasalahan yang telah didefinisikan pada bab pendahuluan. Pada tahapan ini akan dijabarkan metode yang akan digunakan untuk melakukan seleksi LLH dan mekanisme penerimaan solusi.

\subsection{Implementasi}

Pada langkah ini merupakan langkah implementasi desain algoritma yang sudah dibuat pada kerangka kerja HyFlex. Algoritma RL-LA yang telah didesain akan dibangun ke dalam HyFlex dalam bahasa pemrograman Java sehingga menjadi program yang siap digunakan untuk uji coba. Tahap ini dimulai dari persiapan tools hingga implementasi 
program. Mekanisme algoritma Reinforcement Learning secara sederhana memberikan reward dan penalty pada setiap LLH.

Pada tahap awal, setiap LLH diberi skor awal yang sudah ditentukan. Jika LLH yang dipilih dan hasil solusinya dapat diterima, maka skor akan meningkat sampai skor mencapai batas yang ditentukan. Sebaliknya jika hasil ditolak, maka skor akan diturunkan hingga mencapai batas bawah yaitu nol. Pada setiap iterasi, LLH dengan skor tertinggi akan dipilih. Tetapi jika ada lebih dari satu LLH yang memiliki skor sama akan dipilih secara random.

Untuk mekanisme algoritma Late Acceptence sebagai move acceptance dasarnya sama seperti yang sudah dijelaskan pada tinjauan pustaka yaitu dengan membandingkan pada beberapa iterasi sebelumnya.

\subsection{Uji Coba}

Tahap ini merupakan tahap pengimplementasian dan eksperimen dari implementasi algoritma hyper-heuristic yang dilakukan. Uji coba dilakukan untuk mengetahui kinerja dari metode hyper-heuristic yang diimplementasikan.

Hasil dari uji coba digunakan untuk mencari strategi high level heuristic yang tepat untuk menyelesaikan masalah lintas domain. Tahap uji coba ini dilakukan pada kombinasi metode yang sesuai pada desain algoritma hyper-heuristic.

\subsection{Analisa Hasil}

Tahap analisis hasil dikerjakan setelah tahap implementasi dan uji coba pada HyFlex selesai. Analisis hasil digunakan untuk mengkur kinerja metode hyper-heuristic.

Nilai fungsi fitness menjadi nilai patokan yang akan dibandingkan setelah dieksekusi secara berulang kali (31 kali) dari setiap instance pada setiap domain permasalahan (total 30 instance) dengan waktu 60000 milidetik (10 menit).

Kriteria yang perlu diukur untuk membandingkan adalah nilai fungsi fitness terbaik (minimum), median, dan rata-rata, dan beberapa data statistik tambahan seperti nilai minimal, kuartil pertama, median, kuartil ketiga, dan nilai maksimum untuk setiap 30 instance domain permasalahan.

\section{HASIL \& PEMBAHASAN}

Berikut ini dijabarkan hasil uji coba dan analisa yang telah dilakukan serta hasil desain dari algoritma Reinforcement Learning-Late Acceptance (RL-LA). Gambar 3 merupakan pseuodocode dari desain algoritma RL-LA. Pengujian peforma dari metode yang diusulkan dalam mencari solusi optimal. Solusi optimal tidak dapat diukur nilai optimalitasnya karena metode ini adalah metode apporoximate.

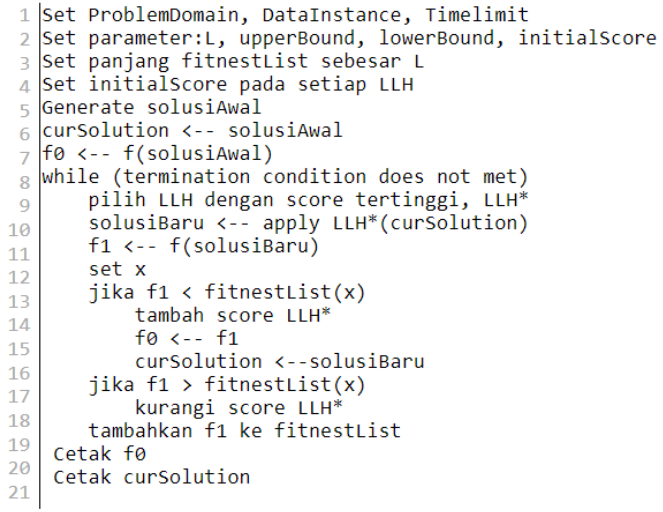

Gambar 3. Desain Algoritma RL-LA

Namun, untuk memilih metode yang terbaik dalam mencari solusi optimal, perbandingan hasil uji coba dengan metode lainnya. Disini, perbandingan dilakukan dengan cara membandingkan metode RLLA dengan metode SR-LA yang diimplementasikan ulang dalam menyelesaikan domain yang sama. Nilai median dan nilai minimum hasil eksekusi nilai fungsi objektif menjadi nilai perbandingan yang akan diuji. Perbandingan nilai median dan nilai minimum untuk melihat metode yang mengalami peningkatan. Metode dikatakan meningkat, jika nilai fungsi objektif lebih minimal. Untuk menghitung nilai peningkatan dengan cara seperti pada persamaan 1 .

Nilai perubahan $(\%)-\left(\left(\frac{a-b}{b}\right) \times 100\right)$

Nilai perubahan digunakan untuk melihat selisih peningkatan atau penurunan nilai fungsi objektif metode RL-LA setiap instance. Jika nilai perubahan bernilai positif, maka terjadi peningkatan. Namun, jika nilai perubahan bernilai negatif, maka terjadi penurunan peforma pencarian RL-LA. Instance yang mengalami peningkatan akan ditotalkan. Total instance yang meningkat dhitung persentase dengan cara seperti persamaan 2. Hasil pengujian nilai median dan nilai minimum metode SA dapat dilihat pada Tabel 2 dan Tabel 3. Nilai dengan cetak tebal pada tabel menunjukkan performa yang lebih baik pada setiap instance.

Instance terbaik $(\%)=\left(\frac{\text { instance } \min }{\text { total } \text { instance }} \times 100\right)$

Tabel 1. Hasil Uji coba RL-LA

\begin{tabular}{|c|c|c|c|c|c|c|c|c|}
\hline 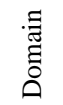 & 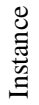 & $\Xi$ & & $\bar{\sigma}$ & & 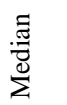 & $\tilde{\partial}$ & $\stackrel{\Xi}{\Sigma}^{\stackrel{x}{z}}$ \\
\hline \multirow[b]{2}{*}{ SAT } & 3 & & 5 & & 8 & 10 & 13 & 28 \\
\hline & 5 & & 4 & & 8 & 12 & 19 & 76 \\
\hline
\end{tabular}




\begin{tabular}{|c|c|c|c|c|c|c|}
\hline \multirow[t]{4}{*}{ 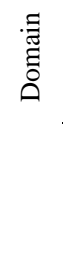 } & 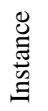 & $\Xi$ & $\bar{\sigma}$ & 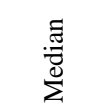 & $\ddot{\theta}$ & $\stackrel{\Xi}{\Sigma}^{\widetilde{E}}$ \\
\hline & 4 & 2 & 4 & 6 & 8 & 48 \\
\hline & 10 & 8 & 11 & 14 & 21 & 56 \\
\hline & 11 & 8 & 12 & 14 & 18 & 25 \\
\hline \multirow{5}{*}{$\mathrm{BP}$} & 7 & 0.16 & 0.17 & 0.18 & 0.19 & 0.19 \\
\hline & 1 & 0.06 & 0.07 & 0.07 & 0.08 & 0.08 \\
\hline & 9 & 0.04 & 0.04 & 0.04 & 0.05 & 0.05 \\
\hline & 10 & 0.13 & 0.13 & 0.13 & 0.13 & 0.14 \\
\hline & 11 & 0.08 & 0.08 & 0.09 & 0.09 & 0.09 \\
\hline \multirow{5}{*}{ FS } & 5 & 17 & 26 & 28 & 33.5 & 41 \\
\hline & 9 & 9749 & 10087 & 10232 & 10765 & 22675 \\
\hline & 8 & 3203 & 3324.5 & 3376 & 3438 & 3698 \\
\hline & 10 & 1664 & 1955 & 2090 & 2219 & 3080 \\
\hline & 11 & 320 & 385 & 410 & 447.5 & 1760 \\
\hline \multirow{5}{*}{ PS } & 1 & 6342 & 6394 & 6403 & 6413 & 6456 \\
\hline & 8 & 26975 & 27021 & 27050 & 27057 & 2721 \\
\hline & 3 & 6400 & 6429 & 6448 & 6462 & 6512 \\
\hline & 10 & 11530 & 11580 & 11595 & 11613 & 11677 \\
\hline & 11 & 26753 & 26817 & 26827 & 26868 & 26913 \\
\hline \multirow{5}{*}{ TSP } & 0 & 49112 & 5045 & 50881 & 51352 & 53110 \\
\hline & 8 & 190321 & 2201046 & 3530137 & 5024672 & 5337433 \\
\hline & 2 & 7005 & 7081 & 7106 & 7196 & 7332 \\
\hline & 7 & 6997 & 7078 & 7092 & 7123 & 7162 \\
\hline & 6 & 55953 & 59775 & 60549 & 61391 & 64289 \\
\hline \multirow{5}{*}{ VRP } & 6 & 90570 & 96548 & 99856 & 102477 & 109688 \\
\hline & 2 & 15759 & 16784 & 17061 & 17948 & 18244 \\
\hline & 5 & 255161 & 316756 & 340975 & 348451 & 380042 \\
\hline & 1 & 21916 & 24023 & 25123 & 26320 & 28589 \\
\hline & 9 & 178289 & 197147 & 203517 & 215239 & 227753 \\
\hline
\end{tabular}

Tabel 2. Pengujian Nilai Median RL-LA dan SR-LA

\begin{tabular}{|c|c|c|c|c|c|}
\hline 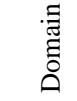 & 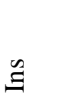 & 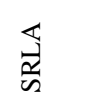 & 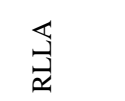 & $\frac{\pi}{\stackrel{\Xi}{0}}$ & \\
\hline \multirow{5}{*}{ SAT } & 3 & 13 & 10 & 3 & $30 \%$ \\
\hline & 5 & 18 & 12 & 6 & $50 \%$ \\
\hline & 4 & 9 & 6 & 3 & $50 \%$ \\
\hline & 10 & 15 & 14 & 1 & $7 \%$ \\
\hline & 11 & 14 & 14 & 0 & $0 \%$ \\
\hline \multirow{5}{*}{$\mathrm{BP}$} & 7 & 0.18241 & 0.179959 & 0.00245 & $1.37 \%$ \\
\hline & 1 & 0.07678 & \multicolumn{2}{|c|}{$\mathbf{0 . 0 7 6 1 1 6} 0.000670458$} & $0.88 \%$ \\
\hline & 9 & 0.04464 & 0.049960 & -0.005310 & $-10.63 \%$ \\
\hline & 10 & 0.12749 & 0.127199 & 0.000299 & $0.24 \%$ \\
\hline & 11 & 0.07451 & 0.085738 & -0.01 & $-13.09 \%$ \\
\hline
\end{tabular}

\begin{tabular}{|c|c|c|c|c|c|}
\hline 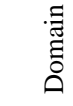 & $\Leftrightarrow$ & $\begin{array}{l}\overleftrightarrow{s} \\
\vec{\sim} \\
\sim\end{array}$ & 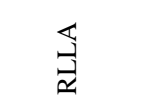 & $\frac{\stackrel{\Xi}{0}}{\stackrel{\Xi}{0}}$ & \\
\hline \multirow{5}{*}{ PS } & 5 & 30 & 28 & 2 & $7.14 \%$ \\
\hline & 9 & 31713 & 10232 & 21481 & $209.94 \%$ \\
\hline & 8 & 3491 & 3376 & 115 & $3.41 \%$ \\
\hline & 10 & 2015 & 2090 & -75 & $-3.59 \%$ \\
\hline & 11 & 370 & 410 & -40 & $-9.76 \%$ \\
\hline \multirow{5}{*}{ FS } & 1 & 6380 & 6403 & -23 & $-0.36 \%$ \\
\hline & 8 & 27000 & 27050 & -50 & $-0.18 \%$ \\
\hline & 3 & 6441 & 6448 & -7 & $-0.11 \%$ \\
\hline & 10 & 11562 & 11595 & -33 & $-0.28 \%$ \\
\hline & 11 & 26798 & 26827 & -29 & $-0.11 \%$ \\
\hline \multirow{5}{*}{ TSP } & 0 & 51327.5 & 50880.83 & 446.6979 & $0.88 \%$ \\
\hline & \multicolumn{2}{|c|}{822520346.6} & 23530136.5 & -1009789.94 & $-4.29 \%$ \\
\hline & \multicolumn{3}{|c|}{$2 \mathbf{7 0 8 0 . 0 1 9 7 2} 7105.80593$} & -25.7862150 & $-0.36 \%$ \\
\hline & \multicolumn{4}{|c|}{$775357.4912 \mathbf{7 0 9 2 . 3 0 3 2 2 2} 68265.18801$} & $962.52 \%$ \\
\hline & 6 & 60192 & 60549 & -356 & $-0.59 \%$ \\
\hline \multirow{5}{*}{ VRP } & 6 & 108811 & 99856 & 8954 & $8.97 \%$ \\
\hline & 2 & 17978 & 17061 & 918 & $5.38 \%$ \\
\hline & 5 & 360081 & 340975 & 19106 & $5.60 \%$ \\
\hline & 1 & 27486 & 25123 & 2363 & $9.40 \%$ \\
\hline & 9 & 224333 & 203517 & 20817 & $10.23 \%$ \\
\hline \multicolumn{2}{|c|}{ Jumlah terbaik } & 11 & 18 & & \\
\hline \multicolumn{2}{|c|}{ Persentase $(\%)$} & $38 \%$ & $62 \%$ & & \\
\hline
\end{tabular}

Tabel 3 Pengujian Nilai Minimum RL-LA dan SR-LA

\begin{tabular}{|c|c|c|c|c|c|}
\hline $\begin{array}{l}\stackrel{\Xi}{\Xi \Xi \Xi} \\
\stackrel{\Xi}{\Xi}\end{array}$ & 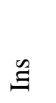 & 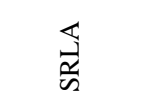 & 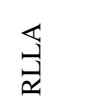 & 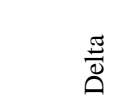 & \\
\hline \multirow{5}{*}{ SAT } & 3 & 7 & 5 & & $40.00 \%$ \\
\hline & 5 & 9 & 4 & 5 & $125.0 \%$ \\
\hline & 4 & 4 & 2 & 2 & $100.0 \%$ \\
\hline & 10 & 8 & 8 & 0 & $0.00 \%$ \\
\hline & 11 & 10 & 8 & 2 & $25.00 \%$ \\
\hline \multirow{5}{*}{$\mathrm{BP}$} & 7 & 0.17368059 & 0.15991 & 0.013768 & $8.61 \%$ \\
\hline & 1 & 0.07109422 & 0.06183 & 0.009265 & $14.98 \%$ \\
\hline & 9 & 0.03970 & 0.04462 & -0.00492 & $-11.04 \%$ \\
\hline & 10 & 0.12613 & 0.12583 & 0.000308 & $0.24 \%$ \\
\hline & 11 & 0.06619 & 0.07891 & -0.01272 & $-16.12 \%$ \\
\hline \multirow{5}{*}{ PS } & 5 & 19 & 17 & 2 & $11.76 \%$ \\
\hline & 9 & 10539 & 9749 & 790 & $8.10 \%$ \\
\hline & 8 & 3273 & 3203 & 70 & $2.19 \%$ \\
\hline & 10 & 1558 & 1664 & -106 & $-6.37 \%$ \\
\hline & 11 & 320 & 320 & 0 & $0.00 \%$ \\
\hline FS & 1 & 6340 & 6342 & -2 & $-0.03 \%$ \\
\hline
\end{tabular}




\begin{tabular}{|c|c|c|c|c|c|}
\hline \multirow[t]{5}{*}{ 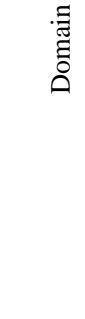 } & 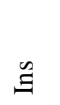 & $\frac{\mathbb{d}}{\stackrel{\Delta}{\infty}}$ & $\underset{\Xi}{\leftrightarrows}$ & $\frac{\pi}{\tilde{0}}$ & \\
\hline & 8 & 26903 & 26975 & -72 & $-0.27 \%$ \\
\hline & 3 & 6408 & 6400 & 8 & $0.13 \%$ \\
\hline & 10 & 11517 & 11530 & -13 & $-0.11 \%$ \\
\hline & 11 & 26743 & 26753 & -10 & $-0.04 \%$ \\
\hline \multirow{5}{*}{ TSP } & 0 & 49632.41 & 49112.41 & 519.99 & $1.06 \%$ \\
\hline & 8 & 21189643 & 21190320.6 & -677.558259 & $0.00 \%$ \\
\hline & 2 & 7003.4058 & 7004.93190 & -1.52609152 & $-0.02 \%$ \\
\hline & 7 & 69915.8509 & 6996.70862 & 62919.14227 & $899.2 \%$ \\
\hline & 6 & 55139.3688 & 55952.7020 & -813.333179 & $-1.45 \%$ \\
\hline \multirow{5}{*}{ VRP } & 6 & 102113.8192 & 90569.70358 & 11544.11562 & $12.75 \%$ \\
\hline & & 15878.64252 & 15759.30365 & 119.3388703 & $0.76 \%$ \\
\hline & & 332666.3338 & 255160.9657 & 77505.36814 & $30.38 \%$ \\
\hline & 1 & 22953.57458 & 21916.35463 & 1037.219947 & $4.73 \%$ \\
\hline & 9 & 200472.334 & 178289.3463 & 22182.98771 & $12.44 \%$ \\
\hline \multicolumn{2}{|c|}{ Jumlah terbaik } & 10 & 18 & & \\
\hline \multicolumn{2}{|c|}{ Persentase (\%) } & $36 \%$ & $64 \%$ & & \\
\hline
\end{tabular}

Dari hasil perhitungan pada pengujian nilai median dan nilai minimum setiap instance, dapat dilihat penerapan metode RL-LA dapat meningkatkan peforma pencarian dalam menemukan solusi optimal pada 18 instance dari 30 instance dengan persentase $64 \%$. Nilai median dan minimum metode RL-LA unggul 28\% dari metode SR-LA. Secara keseluruhan, perbedaan peningkatan RL-LA cukup jauh. Namun, pada beberapa instance mengalami nilai imbang dan penurunan tetapi tidak signifikan. Metode RL-LA lebih baik daripada metode SR-LA untuk seleksi LLH. Akan tetapi, peningkatan dan penurunan tidak hanya diperngaruhi oleh mekanisme seleksi LLH saja, tetapi juga dipengaruhi oleh mekanisme penerimaan solusi. Kombinasi yang tepat dapat meningkatkan peforma dari hiperheuristik. Oleh karena itu, perlu melakukan banyak eksperimen untuk mengkombinasikan kedua mkanisme tersebut. Grafik pada Gambar 4 adalah perbandingan presentase perubahan total nilai median berdasarkan domain permasalahan. Nilai ini diperoleh dari membandingkan nilai fungsi fitness dari solusi yang dihasilkan oleh algoritma RL-LA dibandingkan dengan solusi yang dihasilkan oleh algoritma SRLA.

Perubahan nilai fungsi fitness pada domain permasalahan bin packing dan flow shop mengalami perubahan negative, artinya RL-LA lebih buruk dibanding SR-LA, tetapi tidak terlalu signifikan. Sedangkan pada domain permasalahan SAT, Personnel Scheduling, TSP, dan VRP mengalami perubahan nilai positif yang tinggi, artinya RL-LA lebih baik dibanding SR-LA, khususnya pada permasalahan TSP, dimana RL-LA dapat menghasilkan solusi hampir 10 kali lebih baik $(1000 \%)$ dari solusi yang dihasilkan oleh SR-LA.

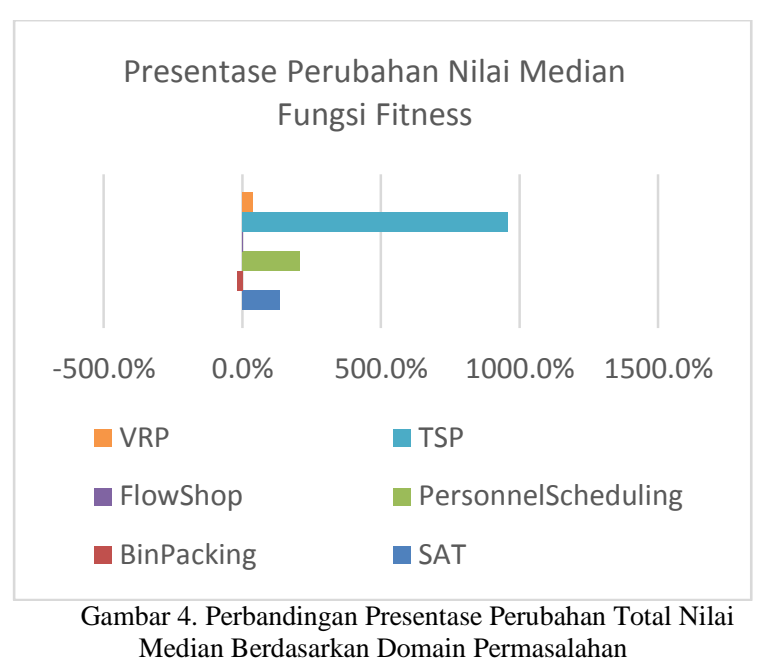

\section{KESIMPULAN}

Berdasarkan hasil studi performa algoritma RLLA dengan algoritma pembanding SR-LA, dapat disimpulkan beberapa hal sebagai berikut:

1) Algoritma seleksi LLH dengan menggunakan Reinforcement Learning dan Late Acceptance sebagai move acceptance dapat meningkatkan kinerja hiperheuristik dalam menyelesaikan permasalahan optimasi lintas domain. Terdapat 4 dari enam domain permasalahan yang mengalami peningkatan kinerja, yaitu SAT, personnel scheduling, TSP, dan VRP, sedangkan pada domain lainnya seperti bin packing dan flow shop mengalami penurunan.

2) Seleksi LLH dengan menggunakan Reinforcement Learning pada dua domain yang telah diuji (bin packing dan flow shop) terjadi penurunan kinerja, tetapi penurunan yang terjadi tidak signifikan.

Untuk penelitian berikutnya, metode untuk mekanisme seleksi low level heuristic yang digunkan pada penelitian ini yaitu Reinforcement Learning dapat dikombinasikan dengan strategi move acceptance selain late acceptance seperti great deluge sehingga diharapkan dapat menghasilkan performa yang lebih bagus.

\section{DAFTAR PUSTAKA}

BURKE, E.K, HYDE, M., KENDALL, OCHOA, G., OZCAN, E., and WOODWARD, J. R., "Handbook of Metaheuristics," Handb. Metaheuristics, 2006.

BURKE, E.K. and KENDALL, G., Search Methodologies. 2013.

BURKE, E.K et al., "Hyper-heuristics: A survey of the state of the art," J. Oper. Res. Soc., vol. 64, no. 12, pp. 1695-1724, 2013.

DJUNAIDY, A., ANGRESTI, N.D. and MUKHLASON, A., Hyper-heuristik untuk 
Penyelesaian Masalah Optimasi Lintas Domain dengan Seleksi Heuristik berdasarkan Variable Neighborhood Search. Khazanah Informatika: Jurnal Ilmu Komputer dan Informatika, 5(1), pp.51-60, 2019.

DRAKE, J.H., KHEIRI, A., OZCAN, E. and BURKE, E.K., 2019. Recent advances in selection hyper-heuristics. European Journal of Operational Research, 285 (2), p.405-428, 2020.

HARMAN, M. and CHICANO, F., "Search Based Software Engineering (SBSE)," J. Syst. Softw., vol. 103, p. 266, 2015.

HIDAYATUL, Y. S., DJUNAIDY, A., \& MUKLASON, A. Solving Multi-objective Vehicle Routing Problem Using Hyperheuristic Method By Considering Balance of Route Distances. In 2019 International Conference on Information and Communications Technology (ICOIACT), pp. 937-942, 2019.

HILLIER, F. and LIEBERMAN, G., Introduction to Operation Research. 2010.

KUMARI, A.C. and SRIVINAS, K.. Hyper-heuristic approach for multi-objective software module clustering. Journal of Systems and Software, 117, pp.384-401, 2016.

KUSUMAWARDANI, D., MUKLASON, A. and SUPOYO, V.A., July. Examination Timetabling Automation and Optimization using Greedy-Simulated Annealing Hyperheuristics Algorithm. In 2019 12th International Conference on Information \& Communication Technology and System (ICTS),pp. 1-6. 2019

MADI, M., MARKOVI, D., and RADOVANOVI, M., "Comparison of Meta-Heuristic Algorithms for," Facta Univ., vol. 11, no. 1, pp. 29-44, 2013.

MCCOLLUM, B. et al., "The Cross-Domain Heuristic Search Challenge - An International Research Competition," 2011

MUKLASON, A., IRIANTI, R.G. and MAROM, A., Automated Course Timetabling Optimization Using Tabu-Variable Neighborhood Search Based HyperHeuristic Algorithm. Procedia Computer Science, 161, pp.656-664, 2019.

MUKLASON, A., SYAHRANI, G.B. and MAROM, A., Great Deluge Based Hyperheuristics for Solving Real-world University Examination Timetabling Problem: New Data set and Approach. Procedia Computer Science, 161, pp.647655,2019

OZCAN, E., BYKOV, Y., BIRBEN, M., and BURKE, E.K., "Examination timetabling using late acceptance hyper-heuristics," 2009 IEEE Congr. Evol. Comput. CEC
2009, pp. 997-1004, 2009.

OCHOA, G, M. H. G., "The Cross-domain Heuristic Search Challenge (CHeSC 2011)," 2011. [Online]. Available: http://www.asap.cs.nott.ac.uk/chesc2011/.

OCHOA, G. et al., "HyFlex: A benchmark framework for cross-domain heuristic search," Lect. Notes Comput. Sci. (including Subser. Lect. Notes Artif. Intell. Lect. Notes Bioinformatics), vol. 7245 LNCS, pp. 136147, 2012.

OCHOA, G. and N.D.., Search-based Approaches and Hyper-heuristics. 2014.

REGO, C., GAMBOA, D., GLOVER, F., and OSTERMAN, C., "Traveling salesman problem heuristics: Leading methods, implementations and latest advances," Eur. J. Oper. Res., vol. 211, no. 3, pp. 427-441, 2011.

SUTTON, R. and BARTO, A., Reinforcement Learning, An Introduction. 2010.

SZEPESVARI, C., "Algorithms for Reinforcement Learning," Synth. Lect. Artif. Intell. Mach. Learn., vol. 4, no. 1, pp. 1-103, 2010. 